Interim Reporting and Managerial Short-termism

Omnia Mahmoud Damarany

\title{
Interim Reporting and Managerial Short-termism
}

\section{Omnia Mahmoud Damarany}

\section{Abstract:}

This research aims to investigate the impact of frequency of financial reporting on managerial short termism. Further, this research investigates the moderate effect of investment sensitivity on the relationship between frequent reporting and managerial short termism. Based on a sample of 76 publicly listed firms in Egyptian Stock Exchange during a five year period (2013-2017), this research employs panel model analysis to empirically test the hypothesized relationships. The results show that there is no difference in the level of investment in terms of capital expenditures, net fixed assets or advertising between quarterly reporting committed firms and quarterly reporting noncommitted firms. The results also show that there is no significant impact of frequent financial reporting on managerial short termism in the existence of investment sensitivity. This null evidence is consistent with the theoretical insight that, for frequent disclosure to affect managerial short termism, it needs to change the mix of hard information versus soft information.

Keywords: Reporting Frequency, Investments, Managerial Short termism, Myopia, Interim Reporting.

العدد الثالث الجزء الأول 19

المجلد العاثر 
Interim Reporting and Managerial Short-termism

Omnia Mahmoud Damarany

\section{Introduction:}

In listed firms, managers are employed to run a business on behalf of the shareholders with the objective to increase firm value, and thus, shareholder wealth (Damodaran, 2012). Although this separation between ownership and control has many practical advantages, it is also associated with information asymmetry, where managers have access to more information than shareholders regarding the real financial position of a firm (Wennergren \& Wentser, 2014). In order to reduce this information asymmetry, financial reports can be disclosed regularly to inform present and potential investors and other stakeholders about current company performance (Butler, Kraft, $\&$ Weiss, 2007).

A more frequent reporting allow the market access to more timely information and will therefore provide investors with the opportunity to make more well-informed investment decisions (Mensah \& Werner, 2008). As investors and analysts base their forecasts of future firm value on the latest earnings of the firm (Stein, 1989), they commonly argue for as often disclosed reports as possible (Mensah \& Werner, 2008). Consequently, stock exchanges and jurisdictions set rules for the frequency of financial reporting to ensure market transparency. This mandated reporting frequency varies across jurisdictions, for example, U.S. and Singapore disclose their interim reports on a quarterly basis

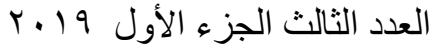

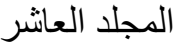


Interim Reporting and Managerial Short-termism

Omnia Mahmoud Damarany

while U.K. and Australia disclose their interim reporting on semiannual basis.

Despite the importance of financial reports in terms of ensuring market transparency, evidence from the market illustrates that there is a difficult trade-off between the benefits and drawbacks of a more or less frequent reporting (Wagenhofer, 2014). Recently, a number of firms have discontinued the practice of providing quarterly reporting to the capital markets. For instance, Coca-Cola, a company known for meeting earnings expectations with enviable consistency, announced that it would stop issuing quarterly earnings guidance, but instead provide more information about its progress towards meeting long-term objectives. Following Coca-Cola, a host of other companies including Alcoa, PepsiCo, and others have announced their intention to discontinue providing quarterly financial reports. Setting long-term economic value aside for the purpose of inflating earnings, just before the next quarterly report is presented, clearly illustrates a possible breach in management duties (Wennergren \& Wentser, 2014).

This shift in focus, where managers sacrifice long-term economic value for the purpose of inflating earnings and meeting short-term goals has been addressed in business research as a phenomenon called managerial short termism. A classic model developed by Stein, (1989) suggests that the behavior of many

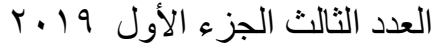

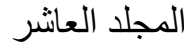


Interim Reporting and Managerial Short-termism

Omnia Mahmoud Damarany

shareholders, who sell their stocks after disappointing earnings announcements, pressures managers to overemphasize earnings at the expense of long-term investments. Correspondingly, Graham, Harvey \& Rajgopal, (2005) find that roughly $80 \%$ of over 400 surveyed managers admit that they would be willing to give up economic value through decreasing discretionary spending in $R \& D$, believing that slightly missing an earnings target will cause trouble in the stock market. When managers are required to disclose their earnings in financial reports more often, this behavior could also be repeated more often.

Evidence on the impact of frequent financial reporting on managerial short termism supports two different views. On the one hand, some studies e.g. (Gigler, Kanodia, Sapra, \& Venugopalan, 2014; K. K. Li \& Tang, 2017) argue that frequent financial reporting encourage the management to focus on short term profits and stock price increases at the expense of the long term growth of the firm through postposing long term investment. On the other hand, other studies e.g. (Kajuter, Klassmann, \& Nienhaus, 2018; Nallareddy, Pozen, \& Rajgopal, 2017) find no relationship between the frequency of financial reporting and the management focus on the long term growth. The evidence supports the notion that, for disclosure to affect myopia, it needs to change the mix of hard information such as earnings versus soft, unverifiable information that firms disclose to the market. Edmans, Fang, \& Lewellen, (2014) demonstrate

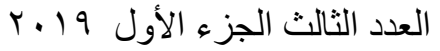

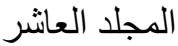


Interim Reporting and Managerial Short-termism

Omnia Mahmoud Damarany

that as long as the market is better at incorporating hard than soft information, disclosing more hard information will bias managers' real decisions toward improving hard measures of performance, such as improving earnings, at the expense of soft measures of performance, such as cutting investments. Accordingly, there exists neither theoretical nor empirical consensus on whether frequent financial reporting encourages or mitigate managerial short termism is still an empirical issue. This research aims to provide further evidence on the ongoing debate regarding the relationship between frequent financial reporting and managerial short termism.

This research attempts to add a contribution to the current debate regarding the relationship between frequent financial disclosure and management focus on the long run. Besides, most of the existing research recently examine frequent financial reporting effects on managerial short termism in the developed countries. This research extends the prior literature by examining the relationship between frequent financial reporting and management focus on long-term growth in a developing country with different institutional setting such as Egypt. Furthermore, it can also extend the broader literature attempting to understand the main determinants of managerial short termism.

The remainder of this paper is organized as follows: Section 2 outlines prior literature and hypotheses tested in this paper.

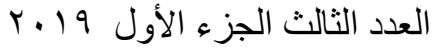

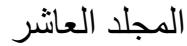


Interim Reporting and Managerial Short-termism

Omnia Mahmoud Damarany

Section 3 outlines the research method including sample selection procedures, data sources, variables measurement, and empirical models employed. Section 4 presents data analysis, statistical techniques applied, and the main findings. Section 5 concludes by discussing the implications of the research findings, highlighting potential limitations and considering future areas for research.

\section{Literature Review and Hypotheses Development:}

Building upon early theoretical work (Stein, 1988, 1989) on managerial short termism, several recent studies e.g. (Ernstberger, Link, Stich, \& Vogler, 2017; Gigler, Kanodia, Sapra, \& Venugopalan, 2014; Kraft, Vashishtha, \& Venkatachalam, 2017) highlight that increasing the reporting frequency can create incentives for managers to make myopic investment decisions that boost short term profits at the expense of longer run firm value. Stein, (1989) shows that managerial short termism can manifest even in efficient capital markets with rational corporate managers and investors as long as two conditions are satisfied. First, corporate managers must exhibit some concern for short term stock prices when evaluating investments. Second, there are information asymmetries between corporate managers and investors about investment expenditures. Therefore, investors may mistakenly attribute lower short-run earnings generated from investments that will yield benefits only

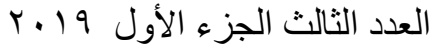

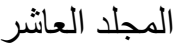


in the long run to managerial misbehavior or poor business prospects, leading to lower stock prices in the short run. This makes corporate managers, who are sufficiently averse to undervaluation of their stock in the short run, unwilling to undertake investments in long-term oriented projects.

Gigler et al., (2014) extend the work of Stein, (1989) by developing a rational expectations equilibrium based on costs and benefits of reporting frequency on managers' investment decisions. The benefit of higher reporting frequency is that it deters managers from investing in negative net present value projects, since peri0dic performance reports enable market prices to impose discipline on the firm's choices. The cost of frequent financial reporting is that it exacerbate incentives of the managers for myopic investment behavior. According to the results of their analytical study, this occurs because increasing the reporting frequency produces shorter term earnings measures that fail to reflect the value of managerial actions that generate wealth only in the long run. In turn, this assures premature evaluation of managers that makes it difficult for them to engage in long-term investments. Thus, financial reporting frequency has real economic consequences for firms.

Providing empirical evidence in support of the above predictions, Ernstberger et al., (2017) study the firms across the European Union, where less than half of the countries adopted

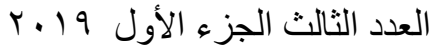

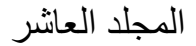


Interim Reporting and Managerial Short-termism

Omnia Mahmoud Damarany

mandatory quarterly reporting while others did not, over the period 2005-2013 to investigate the real effects of reporting frequency. They find that, compared to semi-annual reporters, quarterly reporters generally exhibit higher levels of real activities management in the f0rm of myopic decisions that increase short term cash flows at the expense of long-term value. In particular, this happens in periods when they just meet or beat earnings benchmarks.

Using the transition of US firms from annual reporting to quarterly reporting over the period 1950-1970, Kraft, Vashishtha, \& Venkatachalam, (2017) investigates the effects of increased reporting frequency on firms' investment decisions. They find that higher reporting frequency may cause management to behave myopically by postponing investments to create interim reports that are more attractive to investors. They also find evidence of a decline in future productivity and sales growth subsequent to the reporting frequency increase.

In contrast, another number of recent studies e.g. (Call, Chen, Esplin, \& Miao, 2016; Kajuter, Klassmann, \& Nienhaus, 2018; Nallareddy, Pozen, \& Rajgopal, 2017) find no relationship between the frequency of financial reporting and managerial short termism. These null relationship is consistent with the theoretical insight that, for frequent disclosure to affect myopia, it needs to change the mix of "hard" information such as earnings

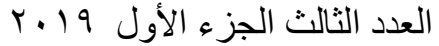

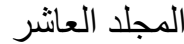


Interim Reporting and Managerial Short-termism

Omnia Mahmoud Damarany

versus "soft", unverifiable information firms disclose to the market. Edmans, Fang, \& Lewellen, (2014) demonstrate that as long as the market is better at incorporating hard than soft information, disclosing more hard information will bias managers' real decisions toward improving hard measures of performance, such as improving earnings, at the expense of soft measures of performance, such as cutting investments.

Using a sample of 548 public firm listed on the stock exchange of Singapore in 2003, Kajuter et al., (2018) investigates the effect of mandatory quarterly reporting on the firm value through three channels: liquidity, compliance cost and short termism. Through the short termism channel, they find no evidence for the myopic investment behavior caused by increased reporting frequency.

Consistent with the results, Nallareddy et al., (2017) exploit the start of mandatory quarterly reporting by the Financial Conduct Authority (FCA) in 2007 and the end of the requirement in 2014 in the United Kingdom to examine corporate and capital market behavior. Using a difference in difference analysis, they find that the imposition of mandatory quarterly reporting has virtually no impact on firms' investment decisions. Also, companies that voluntarily moved back from quarterly to semiannual reporting after 2014 have experienced a reduction in

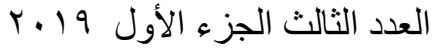

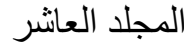


Interim Reporting and Managerial Short-termism

Omnia Mahmoud Damarany

analyst coverage, but no detectable increases in their levels of corporate investments.

Moreover, Call et al., (2016) manually identify 1,709 longterm earnings forecasts issued by 289 unique firms from 20002012, and compare these firms to matched control firms that regularly issue short term earnings guidance. The results show no difference in investment level, investment sensitivity, or the tendency to meet or just beat quarterly earnings between longterm guidance firms and short term earnings guidance firms. Also, short-term guidance issuers manage earnings less and are better innovators, affirming the benefits of short-term guidance.

Based upon this line of argument, the research hypothesis could be formulated as follows:

$H_{01}$ : Frequent financial reporting has no significant impact on managers' investment behaviour.

$H_{01 a}:$ Frequent financial reporting has no significant impact on managers' investment behaviour in terms of capital expenditures.

$H_{01 b}$ : Frequent financial reporting has no significant impact on managers' investment behaviour in terms of net fixed assets.

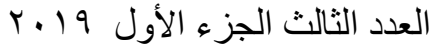

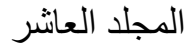


Interim Reporting and Managerial Short-termism

Omnia Mahmoud Damarany

$H_{01 c}:$ Frequent financial reporting has no significant impact on managers' investment behaviour in terms of advertising.

$H_{02}$ : The sensitivity to investment opportunities has no significant impact on the relationship between frequent financial reporting and managers' investment behaviour.

$H_{02 a}$ : The sensitivity to investment opportunities has no significant impact on the relationship between frequent financial reporting and managers' investment behaviour in terms of capital expenditures.

$H_{02 b}$ : The sensitivity to investment opportunities has no significant impact on the relationship between frequent financial reporting and managers' investment behaviour in terms of net fixed assets.

$H_{02 c}$ : The sensitivity to investment opportunities has no significant impact on the relationship between frequent financial reporting and managers' investment behaviour in terms of advertising.

\section{Research Method:}

\subsection{Sample Selection:}

The selected sample is classified into two groups based on the firm's commitment to issue quarterly financial reporting. The first group of the sample is those firms that regularly issue their

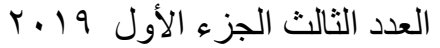

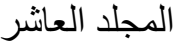


Interim Reporting and Managerial Short-termism

Omnia Mahmoud Damarany

quarterly financial statements. The second group of the sample is firms that are not committed in providing quarterly financial statements for at least two quarters within the fiscal year to ensure that non-committed firms deviate from the regular practice of providing quarterly reporting. This procedure is conducted to overcome the following limitations: First, Empirically identifying the effect of reporting frequency on investment decisions is a challenging task. In Egypt, there is currently no cross-sectional variation in reporting frequency because the Egyptian stock exchange requires all publicly listed firms to report on a quarterly basis since 1996. Second, the difficulty to obtain the historical financial statements within the period in which Egypt changed its reporting regulation from semiannually basis to quarterly basis. Third, because the determinants of quarterly reporting may be associated with investment decisions and the incentives to manage the earnings, the committed firms in providing the quarterly financial reporting may differ systematically from non-committed firms.

This research also depends on financial year-end information directly from the firms' annual reports for several reasons. First, the benefits of long term capital investment projects may not be immediate and take at least three quarters to appear its effects. As investors learn about the future prospects of such investments based on quarterly earnings reports, it is possible that after observing poor quarterly earnings reports for

العدد الثالث الجزء الأول 19

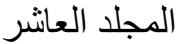


Interim Reporting and Managerial Short-termism

Omnia Mahmoud Damarany

the first few quarters, investors may mistakenly interpret these poor results as a reflection of inferior investment choices made by the manager (Kraft et al., 2017). Second, the majority of data adjustments aimed at meeting earnings goals occur during the fourth quarter, that is, at the end of a fiscal year (Bhojraj et al., 2009). Third, this research cannot rely on quarterly reporting financial statements as roughly the half of the sample consists of the firms that aren't committed in providing quarterly reporting. Finally, because the starting point for the adoption of quarterly reporting depends on firms' financial year-end, identification of the correct financial year-end is essential for the analyses (Kajuter et al., 2018). Thus, focusing on annual earnings ensures greater comparability with previous studies.

The final sample is comprised of 76 publicly listed firms in the Egyptian exchange during a five year sample (2013-2017). Consistent with extent literature, the sample excludes financial services companies (e.g. banks and insurance companies) because of their peculiarities, and firms trading in foreign currency. The sample also excludes firms with insufficient information to calculate any of the independent variables.

\subsection{Data Sources:}

The information used to measure the frequency of financial reporting are obtained from the Egyptian stock exchange (EGX). The financial statement data used in measuring investments are

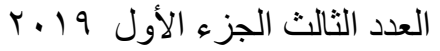

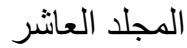


Interim Reporting and Managerial Short-termism

Omnia Mahmoud Damarany

also obtained from the Egyptian stock exchange (EGX). Other financial data used in measuring investment opportunity was collected manually from annual disclosure book.

\subsection{Variables Measurement: \\ 3.3.1. Measuring Frequent Financial Reporting}

Frequent financial reporting is measured as an indicator variable that equal 1 if the firm regularly issue its quarterly financial reporting, and zero otherwise.

\subsubsection{Measuring Managerial Short termism:}

Managerial short termism is a multidimensional concept that has no universally accepted measure. One likely target for managerial short termism is investment. Executives have the incentive to downscale or postpone investment projects which generate value on the long run, in order to boost short term earnings and stock prices.

Kraft et al., (2017) argue that capital investment projects, which commonly generate value over longer horizons, map well into the theory of reporting frequency and myopic underinvestment. According to influential survey, Graham et al., (2005) report that corporate executives admit cutting capital expenditures and avoiding equipment maintenance in order to meet short term earnings targets. Moreover, Asker et al., (2015), Ladika \& Saunter, (2013) as well as Kajuter et al., (2018) find

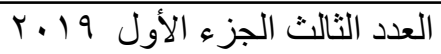

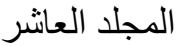


Interim Reporting and Managerial Short-termism

Omnia Mahmoud Damarany

large sample archival evidence that managerial myopia can indeed manifest in the form of reduced capital expenditures, reduced fixed assets. Brochet et al., (2015) find that short-term oriented companies invest less in $R \& D$ and advertising, suggesting that these companies sacrifice investments with longterm pay-offs to maximize their current financial performance.

Following Kraft et al., (2017) and Brochet et al., (2015) this research uses the following three measures of investments as proxies to measure managerial short termism.

(1) Capex, is defined as the amount of capital expenditures scaled by total assets.

(2) Chppe, is defined as the change in net fixed assets scaled by total assets.

(3) Advertising, is defined as advertising expenses scaled by total assets.

\subsubsection{Measuring Investment Opportunities:}

Investment opportunity is an increasingly influential factor that affect investment decisions of the manager. Following Kraft et al., (2017) and Asker et al., (2015), investment opportunities can be captured using Tobin Q, and estimate it as the predicted values of cross-sectional regressions of Tobin's $\mathrm{Q}$ on variables that contain information about firms' marginal product of capital

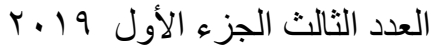

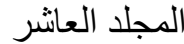


Interim Reporting and Managerial Short-termism

Omnia Mahmoud Damarany

such as ;sales growth, return on assets, book leverage, net income, and year fixed effects.

Tobin $\mathrm{Q}=\alpha+\beta 1$ Growth $+\beta 2 \mathrm{ROA}+\beta 3 \mathrm{LEV}+\beta 4 \mathrm{NI}+\sum$

$\mathrm{YEAR}+\varepsilon$

Where:

Tobin $\mathrm{Q}=$ market value of assets divided by book value of assets.

GROWTH = growth rate in sales, measured as the sales in year $\mathrm{t}$ minus sales in year $\mathrm{t}-1$ and scaled by sales in year $\mathrm{t}-1$.

$\mathrm{ROA}=$ net income divided by total assets.

$\mathrm{LEV}=$ firm leverage, measured as total liabilities divided by total assets.

$\mathrm{NI}=$ net income of the firm.

$\sum$ YEAR is year fixed effects.

$\mathcal{E}=$ error term (residual).

Tobin's Q (TQ) is a reflection of the market's expectations about future profitability contrary to return on assets or gross margin, which are related to current profitability. The advantage of this approach is that it more precisely capture market's valuation of a firm's growth opportunities based on the firm's

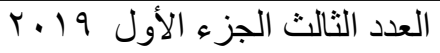

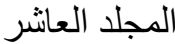


Interim Reporting and Managerial Short-termism

Omnia Mahmoud Damarany

capital productivity and reduces any measurement error in Tobin's Q due to noise or mis-valuation of stock prices.

\subsection{Model Specifications for Hypothesis Testing}

\section{First: Frequent Financial Reporting and Managerial Short termism:}

To test the impact of frequent financial reporting on manager's investment behavior after holding investment opportunity constant $(\mathrm{H} 1)$, the following regression model is estimated:

INVESTMENT $=\alpha+\beta 1 \mathrm{QR}+\beta 2 \mathrm{EBITDA}+\beta 3$ INVESTOPP + $\beta 4 \quad \mathrm{LEV}+\beta 5 \mathrm{CASH}+\beta 6$ SIZE $+\sum$ IND + Eit............................................... Eq (1)

Where:

INVESTMENT is one of the three measures:

*CAPEX $=$ the amount of capital expenditures scaled by total assets.

${ }^{*} \mathrm{CHPPE}=$ the change in net fixed assets scaled by total assets.

*ADVERTISING $=$ advertising expenses scaled by total assets.

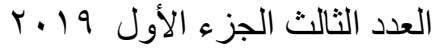

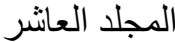


Interim Reporting and Managerial Short-termism

Omnia Mahmoud Damarany

$\mathrm{QR}=$ an indicator variable that equal 1 if the firm is committed in providing quarterly financial statements, and zero otherwise.

EBITDA $=$ operating income before depreciation and amortization scaled by total assets.

INVESTOPP $=$ predicted values from regressions of Tobin Q :

Tobin $\mathrm{Q}=\alpha+\beta 1$ Growth $+\beta 2 \mathrm{ROA}+\beta 3 \mathrm{LEV}+\beta 4 \mathrm{NI}+$ $\sum \mathrm{YEAR}+\varepsilon$

$\mathrm{LEV}=$ long term liabilities scaled by total assets.

$\mathrm{CASH}=$ cash and cash equivalent scaled by total assets.

Size $=$ the natural logarithm of total assets.

$\sum$ IND: industry fixed effects.

$\varepsilon_{\mathrm{j}, \mathrm{t}}=$ error term (residual).

Given that frequent financial reporting is unlikely to be the sole determinant of manager's myopic investment decisions, several control variables were included to proxy for several factors that have been shown to be associated with managerial short termism in the existing literature. These control variables

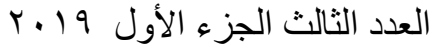

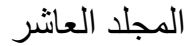


Interim Reporting and Managerial Short-termism

Omnia Mahmoud Damarany

are motivated by recent and contemporaneous studies modelling firm-level investments as follows:

Earnings before interest, tax, depreciation and amortization (EBITDA):

EBITDA as a proxy for profitability is an important factor affecting investment. Call et al., (2016) find evidence that firms with more EBITDA correlates positively with the level of investment.

Leverage:

Chang et al., (2007) as well as Kraft et al., (2017) find that leverage significantly influence the level of investment where firms with lower leverage, less cash constrained, can more easily place improvements in investment opportunities.

Cash:

Cash is another factor that is potentially positively influence investments given that firms with more cash can more readily respond to investment opportunities. Omitting cash holdings and leverage would then bias the results (Call et al., 2016).

Size:

Kajuter et al., (2018) find evidence that firm size significantly influence investment where larger firms potentially

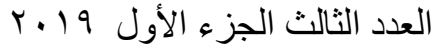

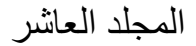


Interim Reporting and Managerial Short-termism

Omnia Mahmoud Damarany

have more funds to invest. Moreover, this variable captures a number of fundamental firm characteristics (e.g. public visibility).

Industry fixed effect is included to control for persistent effects across industries and to avoid any industry level growth shocks coinciding with reporting frequency increases.

\section{Second: Frequent Financial Reporting and Managerial Short termism in the existence of Investment Sensitivity:}

Based on Stein's myopia models (1988, 1989), managers who are concerned with their firm's stock price and boosting their current earnings will tend to forsake good investment opportunities and mislead the market about their firms' worth. On the basis of Equation (1), interacting the investment opportunities with the $\mathrm{QR}$ indicator allows us to compare investment sensitivities of $\mathrm{QR}$ committed firms and $\mathrm{QR}$ noncommitted, then its effect on the level of investments. If $\mathrm{QR}$ committed firms are less sensitive to investment opportunities, this will reflect in reduced level of investment, thereby enhance managerial short termism and vice versa. To test the relationship between frequent financial reporting and managerial short termism in the existence of the sensitivity to investment opportunities (H2), the following regression model is estimated: 
Interim Reporting and Managerial Short-termism

Omnia Mahmoud Damarany

INVESTMENTit $=\alpha+\beta 1$ INVESTOPP $+\beta 2 \mathrm{QR} *$ INVESTOPP $+\beta 3$ EBITDA $+\beta 4$ LEV $+\beta 5$ CASH $+\beta 6$ SIZE $+\sum$ IND + $\varepsilon \ldots \ldots \ldots \ldots . . . . . . \mathrm{Eq}(2)$

Where:

All variables are previously defined.

\subsection{Data Analysis and Results:}

\subsubsection{Descriptive Statistics and Correlation Matrix:}

Table 4.3 panel A presents descriptive statistics for $\mathrm{QR}$ committed firms and panel B presents descriptive statistics for QR non-committed firms.

\section{Table 3.1: Descriptive Statistics}

\section{Panel A: QR Committed Firms:}

\begin{tabular}{c|c|c|c|c|c|c|c|}
\hline & Mean & Median & Maximum & Minimum & Std. Dev. & Jarque-Bera & Probability \\
CAPEX & -0.992386 & -0.993518 & -0.980136 & -0.998385 & 0.004625 & 26.49962 & 0.000002 \\
CHPPE & 0.139835 & 0.111006 & 0.321107 & 0.032716 & 0.085211 & 28.09723 & 0.000001 \\
SIZE & 9.088748 & 9.100639 & 10.86440 & 7.411051 & 0.743610 & 0.412785 & 0.813514 \\
CASH & 0.056361 & 0.050954 & 0.116632 & 0.017117 & 0.026786 & 18.81399 & 0.000082 \\
EBTIDA & 0.060985 & 0.062107 & 0.120218 & 0.014309 & 0.028488 & 12.09566 & 0.002363 \\
TOBIN Q & 2.008150 & 1.718135 & 4.266667 & 0.880000 & 0.940605 & 25.43550 & 0.000003 \\
GROWTH & 0.118842 & 0.116750 & 0.300000 & -0.010000 & 0.077427 & 11.43528 & 0.003287 \\
NI & 18.10965 & 18.12508 & 22.92104 & 13.19306 & 1.724094 & 0.466191 & 0.792078 \\
ROA & 0.040798 & 0.040798 & 0.078631 & 0.002349 & 0.020696 & 13.55844 & 0.001137 \\
LEVERAGE & 0.070180 & 0.059258 & 0.169658 & 0.010995 & 0.044843 & 23.81594 & 0.000007 \\
\hline
\end{tabular}

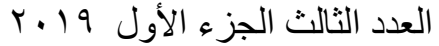

المجلد العانشر 
Interim Reporting and Managerial Short-termism

Omnia Mahmoud Damarany

\section{Panel B: QR Non-committed Firms:}

\begin{tabular}{c|c|c|c|c|c|c|c|}
\hline & Mean & Median & Maximum & Minimum & Std. Dev. & Jarque-Bera & Probability \\
CAPEX & 0.992124 & 0.993603 & -0.979328 & -0.998659 & 0.004976 & 12.20278 & 0.002240 \\
CHPPE & 0.148557 & 0.104075 & 0.309138 & 0.032948 & 0.090682 & 10.69311 & 0.004765 \\
ADV & 13.86495 & 13.60338 & 18.80081 & 8.397283 & 2.632955 & 3.383005 & 0.184243 \\
SIZE & 9.175103 & 9.118904 & 10.62765 & 7.825967 & 0.673768 & 2.314931 & 0.314282 \\
CASH & 0.053486 & 0.044844 & 0.114079 & 0.018456 & 0.028166 & 10.47636 & 0.005310 \\
EBTIDA & 0.057500 & 0.058590 & 0.120218 & 0.013559 & 0.029756 & 5.601938 & 0.060751 \\
TOBIN Q & 2.035417 & 1.770747 & 4.158000 & 0.890000 & 0.924950 & 8.892215 & 0.011724 \\
GROWTH & 0.1060970 .090000 & 0.285000 & 0.000000 & 0.074271 & 7.104709 & 0.028657 \\
NI & 17.94727 & 17.90469 & 22.09818 & 14.25418 & 1.634249 & 1.812693 & 0.403998 \\
ROA & 0.039553 & 0.036773 & 0.078581 & 0.002402 & 0.021237 & 5.021653 & 0.081201 \\
LEVERAGE & 0.0695500 .061062 & 0.173318 & 0.011316 & 0.039869 & 8.330052 & 0.015529 \\
\hline \multicolumn{7}{c}{}
\end{tabular}

As shown in table 4.3 the Mean of CHPPE is 0.139835 for QR committed firms in a comparison to 0.148557 for QR noncommitted firms. Moreover, the Mean of CAPEX is -0.992386 for QR committed firms in a comparison to -0.992124 for QR non-committed firms, which indicates that firms that regularly issue their QR exhibit (marginally) lower level of investment than those firms that are not committed in providing $\mathrm{QR}$. However, the impact of the extent of commitment in providing quarterly reporting is statistically insignificant for all of the investment measures.

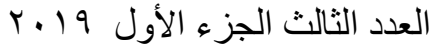

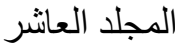


Interim Reporting and Managerial Short-termism

Omnia Mahmoud Damarany

Moreover, table 4.3 also shows that the Mean (median) firm size as measured by natural $\log$ of total assets for the sample firms is 9.08 (9.10) for QR committed firms and 9.17 (9.11) for non-committed firms which approximately match a total asset size of 255 million suggesting that the sample is comprised of mainly medium-to-large sized firms. Table 4.3 panel A also shows that nearly the distribution of firm characteristics is similar to that presented for those presented in panel B.

According to the above descriptive statistics, it can be revealed that the normality distribution of research variables in terms of CHPPE, Firm Size and NI by using the Jarque-Bera test at a significance level greater than (0.05). Moreover, the research variables in terms of Capex, leverage, cash, EBITDA, Tobin Q, Growth and ROA are not normally distributed since the significance of Jarque-Bera statistic is less than (0.05).

\section{Table 3.2: Person Correlation Matrix}

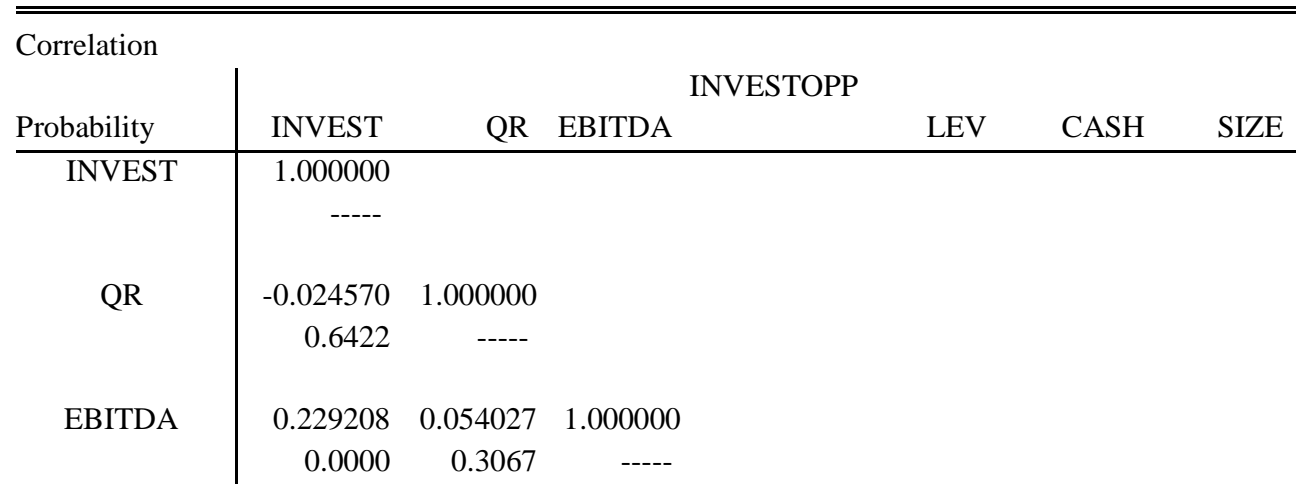

العدد الثالث الجزء الأول 19 بـr

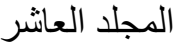


Interim Reporting and Managerial Short-termism

Omnia Mahmoud Damarany

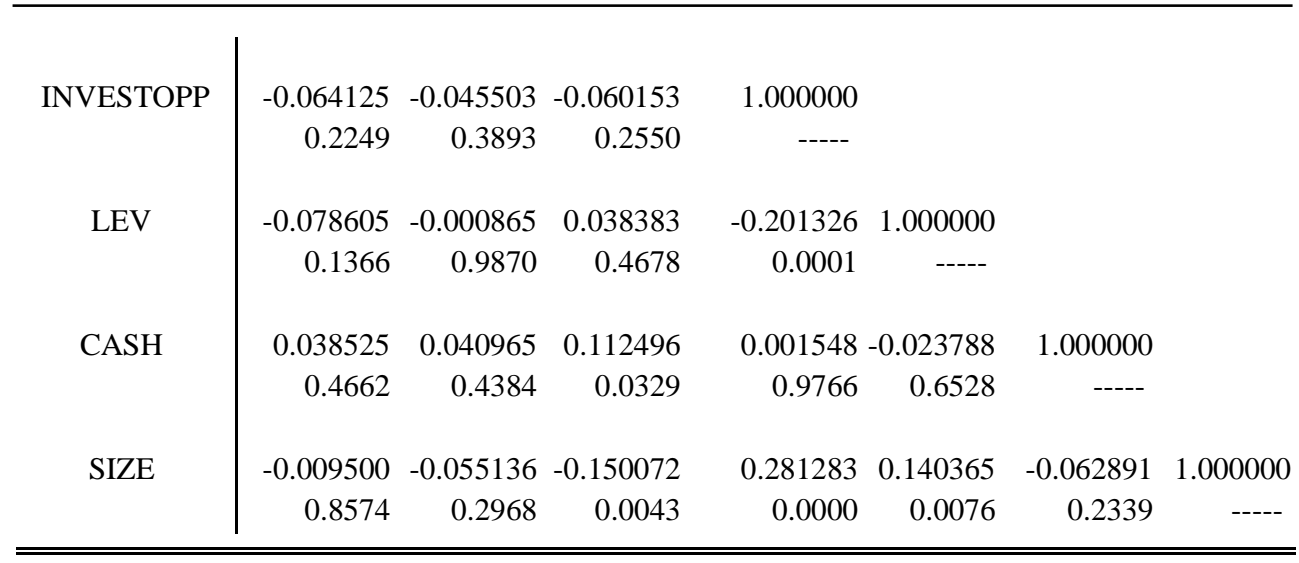

The correlation matrix presented in table 4.6 shows that there is negative and insignificant relationship between the dependent variable INVEST and the independent variable of QR after controlling for investment opportunities and other important firm characteristics. Thus, there is no consistent evidence of differential investment levels exhibited by QR committed firms. It also shows that there is significant positive linear relationship between the independent variable of EBITDA and INVEST at a significance level less than 0.001 which means that firms with more EBITDA correlates positively with the level of investment. Moreover, there is no multicollinearity problem since the highest correlation value between INVESTOPP and Firm Size is (0.28). 
Interim Reporting and Managerial Short-termism

Omnia Mahmoud Damarany

\subsubsection{Hausman Test:}

The central assumption behind random effects model (REM) is that the variation across entities is assumed to be random and uncorrelated with the explanatory variables included in the model. One common method for testing this assumption is to employ a Hausman test to compare the fixed and random effects estimates of coefficients (Hausman, 1978). The null hypothesis underlying the Hausman test is that the fixed effects model (FEM) and REM estimators do not differ substantially. If the null hypothesis is rejected, the conclusion is that REM is not appropriate and thus it is better to use FEM.

\section{Table 3.3: Hausman Test for Correlated Random Effects}

\begin{tabular}{lrrr}
\hline \hline Test Summary & $\begin{array}{r}\text { Chi-Sq. } \\
\text { Statistic }\end{array}$ & Chi-Sq. d.f. & Prob. \\
\hline \hline Cross-section random & 12.407714 & 6 & 0.0535 \\
\hline \hline
\end{tabular}

According to table 4.8 , it can be revealed that the calculated value of the Hausman test is significant at a level less than (0.05). Thus, the null hypothesis which supports the appropriateness of the random effects model is rejected and the alternative hypothesis of the fixed effects model is accepted. 
Interim Reporting and Managerial Short-termism

Omnia Mahmoud Damarany

\section{Summary and Conclusion:}

This research examines the impact of frequent financial reporting on managerial short termism in terms of manager's investment behavior in an institutional setting that differ from those of US and other developed countries. This research also examines the sensitivity to investment opportunities for both firms; those that are committed in providing quarterly reporting and those firms that are not committed.

In order to achieve the main objective of this research, a panel model analysis applying ordinary least square on data of 76 publicly traded companies in Egyptian Stock Exchange over a five year period (2013-2017). The data in this research were obtained from various resources (i.e. Egyptian stock exchange, annual disclosure book). In order to measure frequent financial reporting, this research uses an indicator variable which equals to one for firms that regularly issue their $\mathrm{QR}$, and zero to firms that are not committed in providing their $\mathrm{QR}$. This procedure is a result of the non-cross-sectional variation in reporting frequency nowadays in Egypt, as well as the lack of historical financial reporting over the period in which Egypt has changed its reporting regulation from semiannual basis to quarterly basis in 1996. This research uses three proxies of investment; capital expenditures, the change in net fixed assets and advertising to measure managerial short termism.

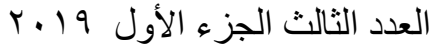

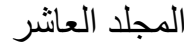


Interim Reporting and Managerial Short-termism

Omnia Mahmoud Damarany

The research major findings show that QR committed firms do not differ from QR non-committed firms in the level of investment in capital expenditures or property, plant, and equipment, or advertising. This finding indicates that there is no direct impact of the frequency of financial reporting on manager's investment behavior. Thereby, $\mathrm{H}_{01}$ is accepted. This finding is inconsistent with some prior literature e.g. (Kraft et al., 2017; Gigler et al., 2014). They find a significant decline in investment which reflects the effect of enhanced managerial short termism following increases in reporting frequency. This research finding is probably differ from these prior literature because the examined sample does not include the real semiannual reporting basis. However, this finding is consistent with Kajuter et al., (2018) applied on Singapore and Nallareddy et al., (2017) applied on U.K. They does not show a significant change in level of investments interms of $R \& D$, capital expenditures, net fixed assets, advertising, or intangible assets following increases in reporting frequency and thus destroy the firm value.

Further, on examination of this second hypothesis, this research finds that the coefficient for the interaction term QR*INVESTOPP is negative, but statistically insignificant suggesting that neither QR committed firms nor QR noncommitted firms exhibit different sensitivity to investment opportunities thereby, there is no effect on the level of investment. Thus, $\mathrm{H}_{02}$ is accepted. This finding indicates that the

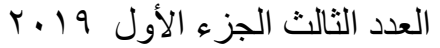

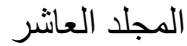


Interim Reporting and Managerial Short-termism

Omnia Mahmoud Damarany

relationship between frequent financial reporting and managerial short termism does not change in the existence of the sensitivity to investment opportunities. Also, the frequency of financial reporting does not affect long term performance of the company. This result finding is inconsistent with Cheng et al., (2007). They find that QR firms exhibit less sensitivity to investment opportunities and the level of investment which enhance managerial short termism. The second hypothesis result is consistent with some prior studies such as; Call et al., (2016) applied on U.S. They find no evidence that long term guidance firms exhibit different investment level or different sensitivity to investment opportunities.

These evidence are consistent with the theoretical insight that, for frequent disclosure to affect myopia, it needs to change the mix of "hard" information such as earnings versus "soft", unverifiable information that firms disclose to the market (Call et al., 2016). If more frequent reporting increase hard information relative to soft information, then it will lead to less investment and more earnings management, and vice versa if it decreases hard information, such as earnings, relative to soft information, such as long term investments. If the ratio of "hard" to "soft" information remains unchanged, then changing the frequency of financial reporting alone would have no impact on managerial short termism. According to the results, frequent financial reporting does not appear to change this mix. Therefore,

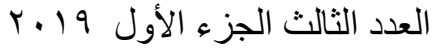

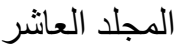


changing disclosure frequency alone is unlikely to change manager's focus on short-term results. This has practical implications for both critics calling for cessation of quarterly financial reporting and managers under pressure to issue quarterly financial reporting.

Overall, this thesis contributes to the growing literature that examines the role of various aspects of financial reporting and disclosure properties on managerial short termism by examining the impact of frequent financial reporting on manager's investment behavior in Egypt. Further, this thesis is timely in informing the current debate calling for ways to curb short termism. Finally, this thesis extends prior literature by documenting economic consequences of mandated disclosure of public information.

\section{Recommendations:}

i. Managerial short termism is an extensive concept that includes many different aspects. A suggestion for future research would be to use another accounting based measures such as $R \& D$ or executive related measures such as the sensitivity of executive equity vesting to stock price to test its relationship with the frequency of financial reporting.

ii. It would be of great interest if future research could find the opportunity to perform an event study using difference- 
Interim Reporting and Managerial Short-termism

Omnia Mahmoud Damarany

in-difference analysis to be able to examine whether same firms that have gone from semi-annual reporting to quarterly reporting have changed their investment behavior.

iii. A comparative study across different countries applies different interim reporting, and cultures would be a valuable aim for further research to compare the results of this research with those found in other countries. Also, further research could replicate this study on a larger sample.

iv. Further research could include additional control variables in the main equation in order to better explain variations in investments, such as, ownership structures.

\section{References:}

Asker, J., Farre-Mensa, J., \& Ljungqvist, A. (2015). Corporate Investment and Stock Market Listing: A Puzzle? Review of Financial Studies, 28(2), 342-390.

Bhojraj, S., Hribar, P., Picconi, M., \& McInnis, J. (2009). Making sense of cents: An examination of firms that marginally miss or beat analyst forecasts. The Journal of Finance, 64(5), 2361-2388.

Brochet, F., Serafeim, G., \& Loumioti, M. (2012). Short-Termism: Don't Blame Investors: HARVARD BUSINESS SCHOOL PUBLISHING CORPORATION 300 NORTH BEACON STREET, WATERTOWN, MA 02472 USA.

Butler, M., Kraft, A., \& Weiss, I. S. (2007). The effect of reporting frequency on the timeliness of earnings: The cases of voluntary and

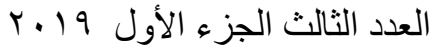

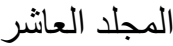


Interim Reporting and Managerial Short-termism

Omnia Mahmoud Damarany

mandatory interim reports. Journal of Accounting and Economics, 43(2-3), 181-217.

Call, A. C., Chen, S., Esplin, A., \& Miao, B. (2016). Long-Term Earnings Guidance: Implications for Managerial and Investor Short-Termism. Retrieved from

Damodaran, A. (2012). Corporate finance: Theory and practice: TPB.

Edmans, A., Heinle, M. S., \& Huang, C. (2016). The real costs of financial efficiency when some information is soft. Review of Finance, 20(6), 21512182.

Ernstberger, J., Link, B., Stich, M., \& Vogler, O. (2017). The real effects of mandatory quarterly reporting. The Accounting Review, 92(5), 33-60.

Gigler, F., Kanodia, C., Sapra, H., \& Venugopalan, R. (2014). How frequent financial reporting can cause managerial short-termism: An analysis of the costs and benefits of increasing reporting frequency. Journal of Accounting Research, 52(2), 357-387.

Kajuter, P., Klassmann, F., \& Nienhaus, M. (2018). The effect of mandatory quarterly reporting on firm value. The Accounting Review.

Kraft, A. G., Vashishtha, R., \& Venkatachalam, M. (2017). Frequent financial reporting and managerial myopia. The Accounting Review, 93(2), 249-275.

Li, K. K., \& Tang, V. W. (2017). Disclosure Frequency Induced Myopia and the Decision to be Public.

Mensah, Y. M., \& Werner, R. H. (2008). The capital market implications of the frequency of interim financial reporting: an international analysis. Review of Quantitative Finance and Accounting, 31(1), 71-104.

Nallareddy, S., Pozen, R., \& Rajgopal, S. (2017). Consequences of mandatory quarterly reporting: the UK experience.

Stein, J. C. (1988). Takeover threats and managerial myopia. Journal of political economy, 96(1), 61-80.

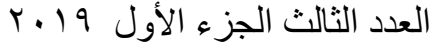

المجلد العاثر 
Interim Reporting and Managerial Short-termism

Omnia Mahmoud Damarany

Stein, J. C. (1989). Efficient capital markets, inefficient firms: A model of myopic corporate behavior. The Quarterly Journal of Economics, 104(4), 655-669.

Van Buskirk, A. (2012). Disclosure frequency and information asymmetry. Review of Quantitative Finance and Accounting, 38(4), 411-440.

Wennergren, M., \& Wentser, T. (2014). Action without Vision?: An Investigation on whether Frequency of Mandatory Financial Reporting affects Managment Focus on Long-term Growth.

Wagenhofer, A. (2014). Trading off costs and benefits of frequent financial reporting. Journal of Accounting Research, 52(2), 389-401. 